\title{
Detecting the fingerprint of drought across Europe's forests: do carbon isotope ratios and stem growth rates tell similar stories?
}

Tommaso Jucker $^{1,2^{*}}$ (D), Charlotte Grossiord ${ }^{3}$, Damien Bonal ${ }^{4}$, Olivier Bouriaud ${ }^{5}$, Arthur Gessler ${ }^{6}$ and David A. Coomes ${ }^{2}$

\begin{abstract}
Background: Understanding how trees respond to drought is critical to forecasting both short and long-term impacts of climate change on forests. The isotopic ratio of ${ }^{13} \mathrm{C}$ to ${ }^{12} \mathrm{C}$ stored in wood - referred to as $\delta^{13} \mathrm{C}$ - is widely used as an indicator of plant water status. Yet whether changes in $\delta^{13} \mathrm{C}$ linked to drought are also associated with declines in annual carbon assimilation and allocation to stem growth remains unclear.

Methods: Here we used tree ring data from over 3000 trees - representing 26 populations of 16 common European tree species sampled at six locations that span more than $20^{\circ}$ in latitude - to test whether drought induces coordinated changes in carbon isotope ratios and stem basal area increments (BAI).

Results: We found that $\delta^{13} \mathrm{C}$ is a reliable indicator of drought across a wide range of species and environmental conditions. All but one of the populations sampled in this study showed a statistically significant increase in $\delta^{13} \mathrm{C}$ under drought conditions. However, when considering the effects of these same drought events on BAl, we found no evidence to suggest that increases in $\delta^{13} \mathrm{C}$ were coupled with significant declines in stem growth. While BAl was $11.9 \%$ lower on average in drought years, this decline in BAI was not significant when analysed across species. In fact, only seven of the 26 populations we sampled exhibited significant declines in BAI under drought conditions - four of these from a single study site in the Carpathian Mountains of Romania.

Conclusions: While $\delta^{13} \mathrm{C}$ responded strongly and consistently to drought across a diverse group of tree species and environmental conditions, we found that most tree species were able to sustain growth even under conditions of low soil water availability. Consequently, while $\delta^{13} \mathrm{C}$ provides a powerful indicator of past drought occurrence, by themselves carbon isotope ratios tell us little about how carbon sequestration and allocation to wood are affected by conditions of low water availability across Europe's forests.
\end{abstract}

Keywords: Basal area increments, Climate change, $\delta^{13} \mathrm{C}$, Dendrochronology, Plant water status, Productivity, Tree rings

\section{Background}

Forests are a key component of the terrestrial carbon cycle and play a critical role in regulating climate by removing $\mathrm{CO}_{2}$ from the atmosphere and storing it in wood (Luyssaert et al. 2008; Beer et al. 2010; Pan et al. 2011). Over the past two decades the world's forests have functioned as a net carbon sink, sequestering as

\footnotetext{
*Correspondence: tommaso.jucker@csiro.au

${ }^{1}$ Ecosystem Change Ecology team, CSIRO Land and Water, 147 Underwood Avenue, Floreat, WA 6014, Australia

${ }^{2}$ Forest Ecology and Conservation group, Department of Plant Sciences,

University of Cambridge, Cambridge, UK

Full list of author information is available at the end of the article
}

much as 30\% of all carbon emissions (Pan et al. 2011). Yet whether this carbon sink will persist under future climate conditions is unclear (Friend et al. 2014), with the likelihood of increasingly frequent and severe droughts and heat waves being a major cause for concern (Allen et al. 2015). Consequently, understanding how trees respond to drought is critical to forecasting both short and long-term impacts of climate change on forests (Clark et al. 2016; Grossiord et al. 2017).

At the level of the leaf, $\mathrm{C}_{3}$ plants (which includes virtually all tree species) respond to low soil moisture availability by closing their stomata to limit water loss through 
transpiration (Bréda et al. 2006; Grossiord et al. 2017). One consequence of reduced stomatal conductance is a drop in the intercellular concentration of $\mathrm{CO}_{2}$ (relative to ambient concentrations outside the leaf), which in turn affects the ratio of ${ }^{13} \mathrm{C}$ to ${ }^{12} \mathrm{C}$ - known as $\delta^{13} \mathrm{C}$ - being fixed by RuBisCO (Farquhar et al. 1982; Leary 1988; Farquhar et al. 1989). Specifically, when stomata are fully open and intercellular concentration of $\mathrm{CO}_{2}$ are high, plants preferentially fix ${ }^{12} \mathrm{C}$ relative to ${ }^{13} \mathrm{C}$, as the lighter isotope diffuses through stomata more rapidly and reacts with RuBisCO more readily (Farquhar et al. 1982). However, as intercellular concentrations of $\mathrm{CO}_{2}$ decline, so too does the degree of fractionation, resulting in a greater proportion of ${ }^{13} \mathrm{C}$ being fixed and thereby an increase in the $\delta^{13} \mathrm{C}$ of photosynthates. As a result, $\delta^{13} \mathrm{C}$ reflects plant water status at the time of carbon fixation, and by analysing the isotopic composition of wood in tree rings we can reconstruct a picture of past drought events (Leavitt 1993; Warren et al. 2001; Gessler et al. 2014). Yet whether $\delta^{13} \mathrm{C}$ signals obtained from tree rings also reflect rates of annual carbon assimilation and allocation to stem growth remains unclear (Ferrio et al. 2003; Peñuelas et al. 2008; Jansen et al. 2013; Belmecheri et al. 2014; Hentschel et al. 2016; Shestakova et al. 2017).

Here we provide the first comprehensive test of whether drought induces coordinated changes in carbon isotope ratios and stem growth rates across Europe's dominant tree species and main forest types, an assumption which is routinely made in the literature but has yet to be rigorously tested. Using tree ring data for 26 populations of 16 common European tree species sampled at six locations that span more than $20^{\circ}$ in latitude, we assess the evidence for the following alternative hypotheses (Fig. 1):

H1: Under drought conditions, trees exhibit an increase in $\delta^{13} \mathrm{C}$ linked to stomatal regulation. This increase in $\delta^{13} \mathrm{C}$ is coupled with a decline in stem growth (Ferrio et al. 2003; Belmecheri et al. 2014).

$\mathrm{H} 2$ : Despite increases in $\delta^{13} \mathrm{C}$ under drought conditions, stem growth varies little between drought and non-drought years (e.g., as a result of the stomatal regulation itself or access to carbon reserves that buffer against strong declines in growth; Hentschel et al. 2016).

H3: Trees show a lagged growth response to drought (Babst et al. 2013; Anderegg et al. 2015). Consequently, coordinated responses in $\delta^{13} \mathrm{C}$ and stem growth only emerge in the year following the drought.

\section{Methods}

\section{Study design}

We sampled tree cores for both carbon isotope analysis and growth estimation from permanently marked forest plots established through the FunDivEUROPE project (Baeten et al. 2013). The FunDivEUROPE plot network consists of 209 forest plots distributed among six study

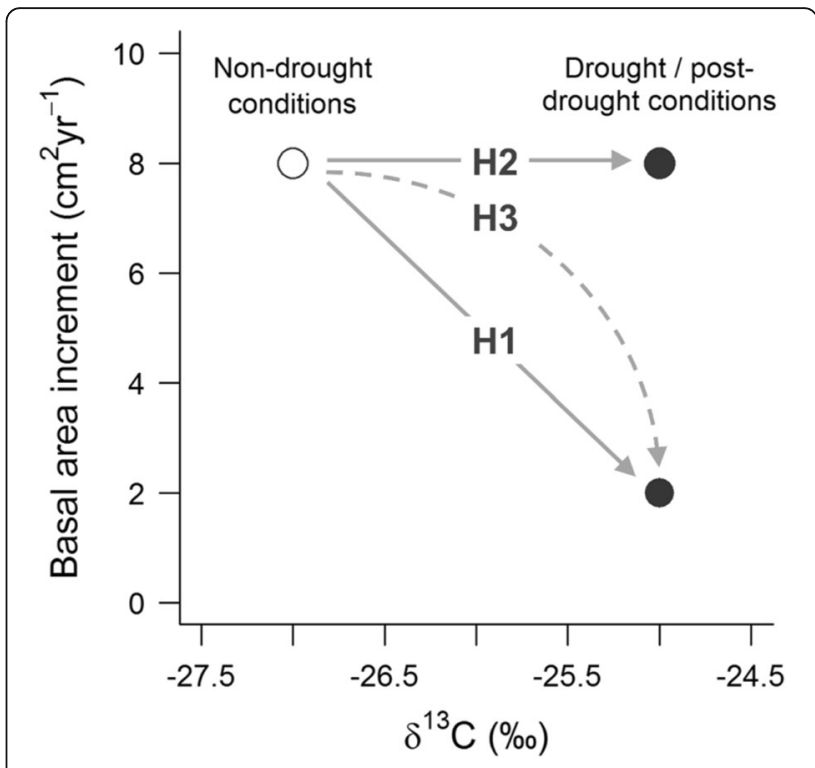

Fig. 1 Schematic diagram of the three hypothesized patterns linking changes in stem growth and $\delta^{13} \mathrm{C}$ between non-drought and drought years. The dashed line symbolizes a lagged growth response to drought (corresponding to $\mathrm{H} 3$ in the main text)

sites across Europe (Table 1). The network was originally designed to explore the functional significance of biodiversity in forests, but is also ideally suited to studying physiological responses of Europe's forests to global change. The six study sites span more than $20^{\circ}$ in latitude and encompass the major forest types found in Europe (EEA 2007), including boreal forests in Finland, hemi-boreal and mixed broadleaved-coniferous forests in Poland, beech forests in Germany, mountainous beech forests in Romania, thermophilous deciduous forests in Italy and Mediterranean mixed forests in Spain. In total, the plot network includes 26 study populations belonging to 16 tree species, several of which feature at more than one site (Table 1). The species pool includes conifers (four species), deciduous broadleaves (11 species) and evergreen broadleaves (one species).

At each site, $30 \times 30 \mathrm{~m}$ permanent plots were established in 2011. Within each plot all stems $\geq 7.5 \mathrm{~cm}$ in diameter were identified to species and permanently marked (12,939 stems in total). For each stem, we recorded the diameter at breast height $(\mathrm{D}$; to the nearest $0.1 \mathrm{~cm}$ using diameter tape) and used the crown illumination index (CII) to characterize crown dominance by scoring stems from 1 (suppressed crown receiving no direct light) to 5 (fully exposed dominant crown; Clark and Clark 1992). CII scores effectively capture the degree to which tree crowns are exposed to light (e.g., Jennings et al., 1999), and were used to select trees for isotope analysis and to model the effects of competition for light on growth (see following sections). 
Table 1 Overview of the FunDivEUROPE plot network

\begin{tabular}{|c|c|c|c|c|c|c|}
\hline & Finland & Poland & Germany & Romania & Italy & Spain \\
\hline Forest type $^{a}$ & Boreal & Hemiboreal & Beech & $\begin{array}{l}\text { Mountainous } \\
\text { beech }\end{array}$ & $\begin{array}{l}\text { Thermophilous } \\
\text { deciduous }\end{array}$ & $\begin{array}{l}\text { Mediterranean } \\
\text { mixed }\end{array}$ \\
\hline Coordinates & $63^{\circ} \mathrm{N}, 30^{\circ} \mathrm{E}$ & $53^{\circ} \mathrm{N}, 24^{\circ} \mathrm{E}$ & $51^{\circ} \mathrm{N}, 11^{\circ} \mathrm{E}$ & $47^{\circ} \mathrm{N}, 26^{\circ} \mathrm{E}$ & $43^{\circ} \mathrm{N}, 11^{\circ} \mathrm{E}$ & $41^{\circ} \mathrm{N}, 2^{\circ} \mathrm{W}$ \\
\hline Number of plots & 28 & 43 & 38 & 28 & 36 & 36 \\
\hline Elevation range (m.a.s.l.) & 80-200 & $135-185$ & $500-600$ & $600-1000$ & $260-525$ & $960-1400$ \\
\hline Mean annual temperature $\left({ }^{\circ} \mathrm{C}\right)$ & 2.1 & 6.9 & 6.8 & 6.8 & 13.0 & 10.2 \\
\hline Mean annual precipitation (mm) & 700 & 625 & 775 & 800 & 850 & 500 \\
\hline Non-drought year & 2004 & 2010 & 2002 & 2001 & 2002 & 2002 \\
\hline Drought year & 2006 & 2002 & 2003 & 2003 & 2003 & 2001 \\
\hline $\begin{array}{l}\text { Water stress index of the drought } \\
\text { year (unitless) }\end{array}$ & 1.5 & 44.6 & 74.2 & 50.6 & 50.1 & 46.4 \\
\hline $\begin{array}{l}\text { Water stress index between } \\
\text { May - Oct of the drought year }\end{array}$ & 1.5 & 40.3 & 59.2 & 35.4 & 49.7 & 44.8 \\
\hline $\begin{array}{l}\text { Number of days with REW } \\
<0.4 \text { during the drought year }\end{array}$ & 13 & 92 & 157 & 171 & 88 & 109 \\
\hline Mean basal area $\left(\mathrm{m}^{2} \mathrm{ha}^{-1}\right)$ & 22.8 & 37.8 & 35.7 & 51.3 & 27.2 & 22.0 \\
\hline \multirow[t]{5}{*}{ Species pool } & Betula pendula & Betula pendula & Acer pseudoplatanus & Acer pseudoplatanus & Quercus ilex & Quercus ilex ${ }^{c}$ \\
\hline & Picea abies & Carpinus betulus & Fagus sylvatica & Fagus sylvatica & Castanea sativa & Quercus faginea \\
\hline & \multirow[t]{3}{*}{ Pinus sylvestris } & Quercus robur & Fraxinus excelsior & Abies alba & Ostrya carpinifolia & Pinus nigra \\
\hline & & Picea abies & Quercus petraea & Picea abies & Quercus cerris & Pinus sylvestris \\
\hline & & Pinus sylvestris & Picea abies & & Quercus petraea & \\
\hline
\end{tabular}

${ }^{a}$ Categories of the European Environment Agency (EEA 2007)

${ }^{b}$ Relative extractable water in the soil, calculated across the entire calendar year

${ }^{c}$ Quercus ilex was not targeted for isotope analysis in Spain due to difficulties in distinguishing between earlywood and latewood

\section{Selecting drought and non-drought years}

To test how drought influences both carbon isotope discrimination and stem growth, we used the BILJOU water balance model (Granier et al. 1999) to characterize annual soil water availability at each site between 1997 and 2010 . Using the output of the model we then identified drought and non-drought years for each FunDivEUROPE site, as is described in detail in Grossiord et al. (2014,b). Briefly, the BILJOU model uses daily meteorological data (precipitation, global radiation, air temperature and humidity, wind speed), alongside information on soil water holding capacity and leaf area index to predict temporal variation in soil water content. Daily meteorological data were obtained from the CGMS database of interpolated meteorological data (AGRI4CAST, http://mars.jrc.ec.europa.eu/mars), while soil water holding capacity and leaf area index were assessed in situ. Specifically soil water holding capacity was estimated on the basis of soil depth and type, while leaf area index was quantified using an LAI-2000 analyser (LI-COR).

Using these data, the BILJOU model estimates the daily relative extractable water in the soil (REW, unitless). REW is defined as the ratio between available soil water and maximum extractable water (i.e., water holding capacity) and varies between 1 (field capacity) and 0 (permanent wilting point). When REW > 0.4, soil water conditions are considered non-limiting for transpiration and the rate of stomatal conductance depends primarily on air vapour pressure deficit and irradiance. Instead, when REW $<0.4$ soil water shortages induce a drop in stomatal conductance and thus in leaf gas exchange for a large range of tree species (although we acknowledge that the magnitude of these responses is likely species-specific; Granier et al. 1999). From the daily REW estimates we calculated an annual water stress index for each site which cumulates daily REW deficits over the course of the year as: $\frac{1}{0.4} \times \sum_{j}(0.4-$ $\left.R E W_{j}\right)$, where $j$ corresponds to the days when REW $<0.4$ (Granier et al. 1999). For each site we then randomly selected a drought year from the three driest years over the 1997-2010 period, and a non-drought year to act as a control among years with a water stress index $<6$ (set as an arbitrary threshold). Drought and non-drought years selected for each study site are listed in Table 1 (see Grossiord et al. 2014 for further details on the selection of drought and non-drought years).

We note that ideally we would have liked to select multiple drought and non-drought years from each site, in order to better tease apart the abiotic and biotic drivers of isotopic signatures and growth trends. However, logistic constraints meant we could either sample multiple years for a small subset of species and/or sites, or we could 
sample across the entire species pool, but only for two contrasting years at each site. As the main goal of our analysis is to understand whether or not carbon isotope ratios and stem growth show a clear and coordinated response to drought across Europe's forests, we chose to focus on the later of these two options. Further work will be needed to tease apart the ecological, physiological and environmental mechanisms that underpin the general relationships we uncover here.

\section{Carbon isotope analysis}

We used wood sampled obtained from dated tree cores to measure the ratio of ${ }^{13} \mathrm{C}$ to ${ }^{12} \mathrm{C}$ - known as $\delta^{13} \mathrm{C}$ - in both drought and non-drought years for each target species across the six study regions. A total of 1467 tree cores were collected for this purpose (giving an average of 59 trees per species at each site), the sampling and processing of which is described in detail in Grossiord et al. (2014,b). Cores were collected between March and October of 2012 for a subset of trees in each plot using a $5.15 \mathrm{~mm}$ diameter increment borer (Haglöf AB, Sweden). Trees were selected for coring at random, but only dominant and codominant trees (defined on the basis of D and CII) were target for isotope analysis to avoid the confounding effect of shading on $\delta^{13} \mathrm{C}$ patterns (Ferrio et al. 2003). Samples were oven-dried for $72 \mathrm{~h}$ at $60^{\circ} \mathrm{C}$ to reach constant weight before being filed with a scalpel for tree-ring dating. Because photosynthates from one growing season can be remobilized and allocated to earlywood formation in the following year (Offermann et al. 2011), thereby potentially confounding isotope - climate signals, we only sampled the latewood of the two target years [see Dietze et al. (2014) for a more in depth discussion on remobilization of non-structural carbohydrates in trees]. Due to difficulties in distinguishing between earlywood and latewood for samples obtained from Quercus ilex trees in Spain, this population was excluded from further isotopic analyses. Wood fragments from a given species in a given plot were pooled to obtain enough material for carbon isotope analyses $\left(n=3-6\right.$ trees species ${ }^{-1}$ plot $\left.^{-1}\right)$. Wood sampled were then ground, yielding between 0.4 and $1.5 \mathrm{mg}$ of wood powder, weighed using a high-precision scale (MX5, Mettler Toldedo, Viroflay, France), placed in tin capsules, and analysed at the Stable Isotope Facility of UC Davis, California, USA with a PDZ Europa 20-20 isotope ratio mass spectrometer (Sercon Ltd., Cheshire, UK). Because the amount of ${ }^{13} \mathrm{C}$ in plants is naturally very low, $\delta^{13} \mathrm{C}$ (\%) is typically expressed in relation to a standard as follows:

$$
\delta^{13} C=\left(\frac{{ }^{13} C_{\text {plant }} /{ }^{12} C_{\text {plant }}}{{ }^{13} C_{\text {std }} /{ }^{12} C_{\text {std }}-1}\right) \times 1000
$$

where ${ }^{13} \mathrm{C}_{\text {plant }} /{ }^{12} \mathrm{C}_{\text {plant }}$ and ${ }^{13} \mathrm{C}_{\text {std }} /{ }^{12} \mathrm{C}_{\text {std }}$ are the isotope ratios of the wood samples and of the Vienna Pee Dee Belemnite (VPDB) standard, respectively.

Plot-level values were used to calculate the mean $\delta^{13} \mathrm{C}$ ( $\pm 95 \%$ confidence intervals) of each species at each site (25 populations in total after having excluded Quercus ilex in Spain) for both drought and non-drought years $\left(\delta^{13} \mathrm{C}_{\mathrm{dry}}\right.$ and $\delta^{13} \mathrm{C}_{\mathrm{wet}}$, respectively). Using these data we then calculated the mean change $( \pm 95 \%$ confidence intervals) in $\delta^{13} \mathrm{C}$ between drought and non-drought years $\left(\Delta \delta^{13} \mathrm{C}\right.$, defined as $\left.\delta^{13} C_{\text {dry }}-\delta^{13} C_{\text {wet }}\right)$ across all study populations.

\section{Tree growth estimation}

In addition to using tree cores for isotope analyses, we also used them to assess growth responses to drought. Tree cores collected to measure growth were collected at the same time as those for isotope analysis, but the number of trees samples was larger (2950 in total, for an average of 113 cores per species at each site, of which those cored for isotopes were mostly a subset). While for isotopes we only sampled large dominant trees, for growth we wanted to explicitly account for the dependency of growth on tree size and therefore used a sizestratified random sampling approach to select trees for coring that would ensure all size classes would be represented by the sample [see Jucker et al. (2014) and Jucker et al. (2016) for details].

Once collected, wood cores were stored in polycarbonate sheeting and allowed to air dry before being mounted on wooden boards and sanded with progressively finer grit sizes. A high resolution flatbed scanner (2400 dpi optical resolution) was then used to image the cores. Yearly radial growth increments $\left(\mathrm{mm} \mathrm{yr}{ }^{-1}\right)$ were measured for each cored tree from the scanned images. To minimise measurement errors associated with incorrectly placed ring boundaries, each sample was cross-dated against a species-level reference curve obtained by averaging all ring-width chronologies belonging to a given species from a given site. Both radial growth measurements and crossdating were performed using the CDendro software suite (Cybis Elektronik \& Data, Saltsjöbaden, Sweden). Radial increments were then converted to basal area increments $\left(B A I\right.$, in $\left.\mathrm{cm}^{2}\right)$. To do this we first reconstructed each tree's past diameters by progressively subtracting annual diameter increment (assumed to be twice the radial growth) from its current day diameter which was measured in the field in 2012. We then calculated each years' BAI as: $\left(\pi \times\left(D_{t 2} / 2\right)^{2}\right)-\left(\pi \times\left(D_{t 1} / 2\right)^{2}\right)$, where $D_{\mathrm{t} 2}$ is the tree's diameter in the most recent time period (e.g., end of 2011) and $D_{t 1}$ is its diameter at the previous time step (2010 in this case).

Because the extent to which trees are affected by drought is known to be size-dependent (e.g., Zang et al. 2012; Bennett et al. 2015; Grote et al. 2016), directly 
relating growth and isotope values without accounting for differences in the size distribution of trees used to calculate them could affect results. To address this issue, we developed a statistical model that explicitly accounts for the effect of tree size on growth, and then used the model to estimate the stem growth of a tree of comparable size to that sampled for isotopes for each of the 26 study populations (see below for details). The model was fit separately to data from the drought and non-drought year, as well as to data from one year post-drought in order to test for lagged growth response to drought. Specifically, for each species at each site we modelled $\mathrm{BAI}$ as the following function of D and CII:

$$
\log (B A I)=\rho_{0}+\rho_{1} \times \log (D)+\rho_{2} \times C I I+\varepsilon
$$

where $\rho_{0-2}$ are parameters to be estimated from the data, and $\varepsilon$ is the residual error. The model structure follows that of Jucker et al. (2014) and Jucker et al. (2016), where BAI is expressed as a power-law function of D (log-log relationship; Rüger et al. 2012), while competitive inhibition by taller neighbours is assumed to be an exponential function of CII (log-linear scale; Caspersen et al. 2011).

Using eq. (2), for each study population we estimated the BAI ( $\pm 95 \%$ confidence intervals) of a tree with a stem diameter in the 75th percentile and $\mathrm{CII}=4$ (corresponding to a tree with $\geq 90 \%$ of its vertically projected crown exposed to full overhead light; Clark and Clark 1992) under drought conditions $\left(\mathrm{BAI}_{\mathrm{dry}}\right)$, in the non-drought year $\left(\mathrm{BAI}_{\mathrm{wet}}\right)$, and one year post-drought $\left(\mathrm{BAI}_{\mathrm{dry}}+1\right)$. From these we then computed the percentage change in

BAI between drought and non-drought years as: $\triangle B A I$ $=\left(\frac{1-B A I_{d r y}}{B A I_{\text {wet }}}\right) \times 100$; and between one year post-drought and non-drought conditions as: $\triangle B A I_{\text {lag }}=\left(\frac{1-B A I_{\text {dry }}+1}{B A I_{\text {wet }}}\right)$ $\times 100.95 \%$ confidence intervals for $\triangle \mathrm{BAI}$ and $\triangle \mathrm{BAI}_{\mathrm{lag}}$ were estimated using Monte Carlo simulations that account for the uncertainty in $\mathrm{BAI}_{\text {dry }}, \mathrm{BAI}_{\text {wet }}$ and $\mathrm{BAI}_{\text {dry }+1}$ values. Note that because in Spain the year post-drought coincided with the year that was selected as the nondrought control (see Table 1), we were unable to calculate $\triangle \mathrm{BAI}_{\text {lag }}$ for trees at this site.

\section{Quantifying the effects of drought on carbon isotope ratios and basal area increments}

To test whether drought had a consistent effect on isotope ratios and growth across all study populations, we used one-sample $t$-tests to determine whether mean $\Delta \delta^{13} \mathrm{C}$, $\triangle \mathrm{BAI}$ and $\triangle \mathrm{BAI}_{\text {lag }}$ values differed significantly from zero. Additionally, we also tested whether isotopic and growth responses to drought differed among study sites or between functional groups (conifers vs broadleaves) using a two-way ANOVA with a Tukey test to correct for multiple comparisons. Lastly, responses of individual study populations to drought were assessed by observing whether the $95 \%$ confidence intervals of $\Delta \delta^{13} \mathrm{C}, \Delta \mathrm{BAI}$ and $\Delta \mathrm{BAI}_{\text {lag }}$ overlapped with zero or not.

To determine whether increases in $\delta^{13} \mathrm{C}$ in response to drought are coupled with declines in BAI (H1) we calculated the Pearson's correlation coefficient $(\rho)$ between $\Delta \delta^{13} \mathrm{C}$ and $\Delta \mathrm{BAI}$ values of all study populations. A negative correlation between $\Delta \delta^{13} \mathrm{C}$ and $\Delta \mathrm{BAI}$ would provide support for $\mathrm{H} 1$, and would suggest that $\delta^{13} \mathrm{C}$ can be used to quantitatively assess the impacts of drought on tree growth (Fig. 1). Instead, assuming an increase in $\delta^{13} \mathrm{C}$ between drought and non-drought years, a lack of correlation between $\Delta \delta^{13} \mathrm{C}$ and $\Delta \mathrm{BAI}$ would suggest that trees are able to maintain growth rates even if stomatal conductance is reduced $(\mathrm{H} 2)$. Alternatively, a lack of correlation between $\Delta \delta^{13} \mathrm{C}$ and $\Delta \mathrm{BAI}$ could also indicate that growth tends to exhibit a lagged response to drought (H3). To test whether this is the case, we correlated $\Delta \delta^{13} \mathrm{C}$ and $\Delta \mathrm{BAI}_{\text {lag }}$ values, with the expectation that a negative correlation between the two would provide support for $\mathrm{H} 3$ (Fig. 1). All analyses were conducted using the $\mathrm{R}$ statistical software ( $\mathrm{R}$ Core Development Team 2016).

\section{Results}

Changes in carbon isotope ratios and basal area increments in response to drought

The ratio of ${ }^{13} \mathrm{C}$ to ${ }^{12} \mathrm{C}$ increased significantly under drought conditions in 24 of the 25 study populations for which isotopic analysis were conducted $\left(\Delta \delta^{13} \mathrm{C}\right.$ between non-drought and drought year $=0.99 \%, P<0.001$; Fig. 2a). Across the study sites the magnitude of the increase ranged between $1.29 \%$ in Finland to $0.76 \%$ in Spain, but did not differ in a statistically significant way among any of the regions. On average, we found that broadleaves had significantly lower $\delta^{13} \mathrm{C}$ values compared to conifers $(-27.10 \%$ o compared to $-26.18 \%$ o in non-drought conditions, $P=0.003$, and $-26.20 \%$ compared to $-25.03 \%$ in the drought year, $P<0.001$ ). However, the magnitude of the variation in $\delta^{13} \mathrm{C}$ between drought and non-drought years was similar in the two functional groups $\left(\Delta \delta^{13} \mathrm{C}=0.90 \%\right.$ and $1.15 \%$ respectively, $P=0.22$ ).

In contrast, while BAI was $11.9 \%$ lower on average during the drought year, this decline in BAI in response to drought was not significant when analysed across species $(P=0.15)$. Only seven of the 26 populations showed a significant decline in BAI under drought conditions (Fig. 2b). Four of these were from a single site (Romania, where BAI declined by $39.8 \%$ under drought conditions, significantly more than at any other site), while three constitute separate populations of a single species (Picea 

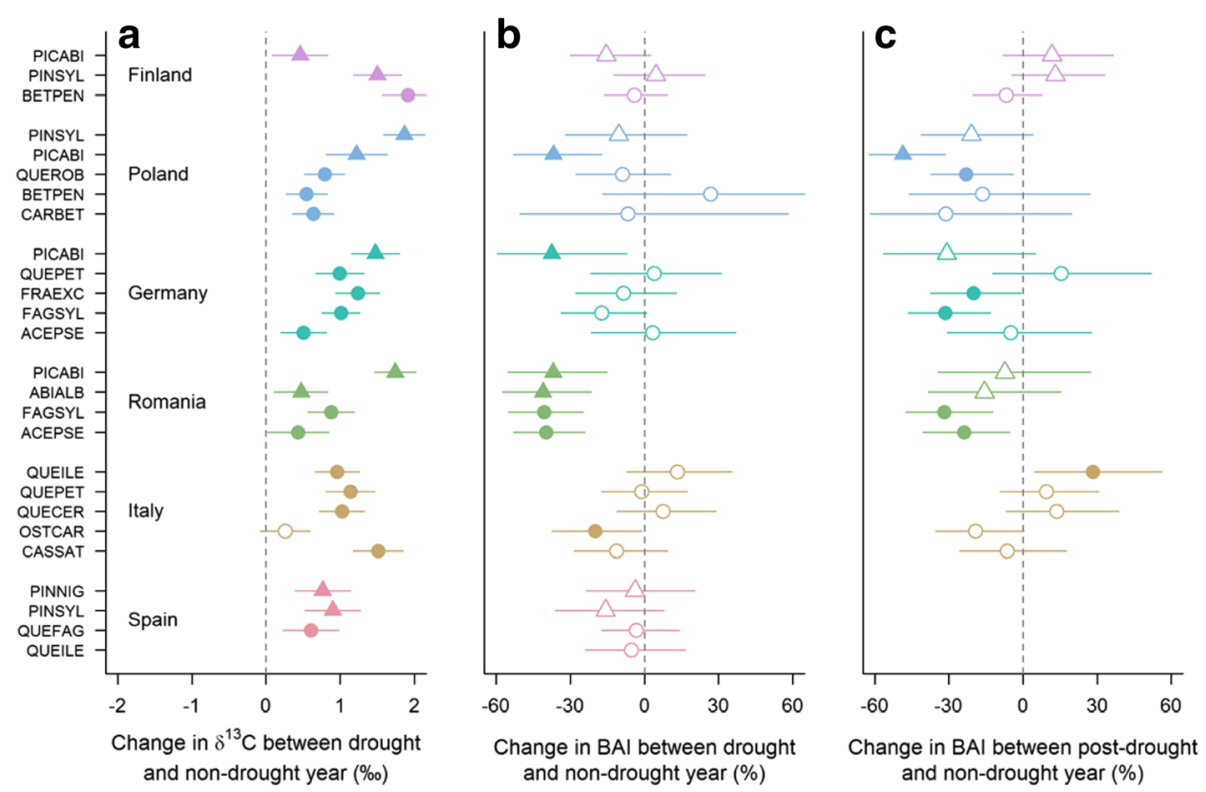

Fig. 2 Change in species (a) $\delta^{13} C_{\text {, }}$ (b) basal area increments (BAI) between drought and non-drought years, and (c) difference in BAl one year post drought and non-drought conditions. Species names are abbreviated using the first three letters of the genus and species name (see Table 1 for full species names). Circles are broadleaved species, while triangles represent conifers. Filled symbols indicate differences that are significantly different from zero, with error bars corresponding to 95\% confidence intervals. Note that in panel (a) Quercus ilex was not targeted for isotope analysis in Spain due to difficulties in distinguishing between earlywood and latewood. In panel (c) species from Spain are not shown because for this site the year post-drought coincided with the year that was selected as the non-drought control (see Table 1 for details)

abies) which were sampled at multiple sites along the latitudinal gradient. When comparing the response of conifers and broadleaves, we found that the broadleaves were only marginally less susceptible to drought $(\triangle \mathrm{BAI}=-21.5 \%$ and $-6.9 \%$ respectively, $P=0.07)$.

$H 1$ versus $H 2$ : are increases in $\delta^{13} C$ in response to drought coupled with declines in BAI?
When we compared changes in $\delta^{13} \mathrm{C}$ and BAI between drought and non-drought years, we found no evidence that the magnitude of changes in carbon isotope ratios were coupled with those in stem growth [Fig. 3; Pearson's correlation coefficient $(\rho)$ between $\Delta \delta^{13} \mathrm{C}$ and $\Delta \mathrm{BAI}$ between drought and non-drought years $=-0.03, P=0.87$ ]. Across all study species, only Picea abies - which was sampled at four
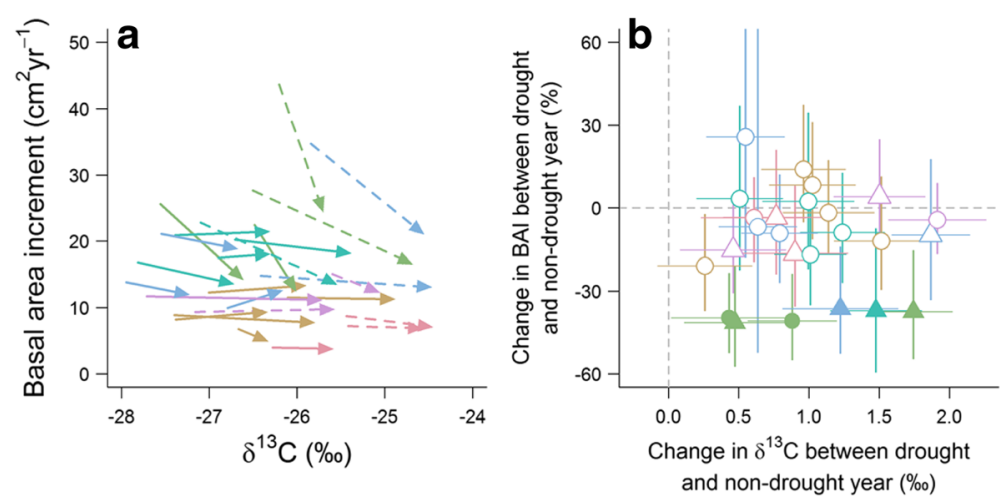

Fig. 3 Relationship between changes in $\delta^{13} \mathrm{C}$ and those in basal area increments (BAl) between drought and non-drought years across all study populations. In panel (a) the start of the arrow corresponds to the non-drought year, while the tip indicates $\delta^{13} \mathrm{C}$ and $\mathrm{BAl}$ values under drought conditions. Arrows that point to the right indicate an increase in $\delta^{13} \mathrm{C}$ between non-drought and drought years, while arrows that point down correspond to a decline in BAI in response to drought. Continuous arrows denote broadleaved species, while conifers are shown as dashed lines. Panel (b) relates changes in BAl between drought and non-drought years (i.e., values reported in Fig. $2 \mathrm{~b}$ ) to ones in $\delta^{13} \mathrm{C}$ (shown in Fig. 2a). Circles are broadleaved species, while triangles represent conifers. Filled symbols indicate species for which changes in $\delta^{13} \mathrm{C}$ and BAI were both significantly different from zero, with error bars correspond to $95 \%$ confidence intervals. The colour scheme of the arrows and points follows that of Fig. 2 
sites along the latitudinal gradient - showed a clear association between increased $\delta^{13} \mathrm{C}$ and decreased growth under drought conditions $(\triangle \mathrm{BAI}=-31.7 \%$ on average; Fig. 2$)$. This is in contrast to species such as Pinus sylvestris (sampled at three sites), which showed a strong drought signal in carbon isotope ratios, but only a marginal and non-significant decline in growth ( $\triangle \mathrm{BAI}=-7.2 \%$ on average, Fig. 2 ).

H3: do trees show a lagged growth response to drought?

Similarly, while on average BAI one year post-drought remained $11 \%$ lower than in the non-drought year (Fig. 2c), across species this trend did not emerge as statistically significant $(P=0.65)$. Six of 22 sampled populations showed significantly lower growth one year-post drought (three of which had also exhibited depressed BAI in the drought year itself; Fig. 2b-c). Again, we found no relationship between the magnitude of a species' increase in $\delta^{13} \mathrm{C}$ during drought and its decline in growth one year post-drought (Fig. 4; $\rho=0.05, P=0.82$ ). Of the species that exhibited drought legacy effects, Fagus sylvatica showed significantly lower growth at both sampled sites in the post-drought year $\left(\triangle \mathrm{BAI}_{\text {lag }}=-31.6 \%\right.$ on average, Fig. $\left.2 \mathrm{c}\right)$. In contrast Picea abies - which exhibited the strongest declines in growth under drought conditions (Fig. 2b) - showed signs of recovery in the post-drought year at three of the four sampled sites (Fig. 2c). More generally, when comparing the growth response of conifers and broadleaves one year post-drought we found no significant differences among the two groups $\left(\Delta \mathrm{BAI}_{\mathrm{lag}}=-14.0 \%\right.$ and $-9.9 \%$ respectively, $\left.P=0.99\right)$.

\section{Discussion}

Across a wide range of environmental conditions, forest types and tree species we found carbon isotope ratios of wood to be a strong and reliable indicator of past drought occurrence (Fig. 2a). However, despite this clear physiological signal of drought on $\delta^{13} \mathrm{C}$, we only found a weak and context-dependent effect of these same drought events on tree growth (Fig. 2b). Previous studies have suggested that the relationship between carbon isotopes and growth might not be a simple one (Ferrio et al. 2003; Peñuelas et al. 2008; Jansen et al. 2013; Hentschel et al. 2016; Shestakova et al. 2017), but to our knowledge none had explored the relationship across a broad enough range of species and environmental conditions to draw this conclusion robustly. The relatively small declines in growth we observed in response to drought suggest that most European tree species are on average - able to maintain growth under conditions of low soil water availability.

This is not to say that water availability is not a key factor in determining tree growth across Europe's forests (Boisvenue and Running 2006; Babst et al. 2013). In fact, previous analyses of stand-level climatic determinants of productivity across the FunDivEUROPE plot network revealed that with the exception of Finland, where growth was primarily temperature-limited, water availability was the primary driver of inter-annual variation in wood production (Jucker et al. 2014; Jucker et al. 2016). However, what these analyses also clearly showed was that the intensity and timing of drought events was just as important in determining annual growth patterns. Taking the sites in Spain and Italy as an example, year-to-year variation in productivity in these drought-prone Mediterranean forests was only weakly correlated with cumulative water shortages across the year, and instead depended strongly on water availability during the early stages of the growing season (Jucker et al. 2016). Consequently, while $\delta^{13} \mathrm{C}$ is a useful indicator of past drought events, changes in these isotopic signatures may not necessarily translate directly to changes in annual growth (Fig. 3). In this respect, understanding the climatic triggers of tree growth - and how these vary among forest types, tree species and locally adapted populations - is critical to forecasting carbon dynamics in the face of climate change (Frank et al. 2015). Only by doing this will
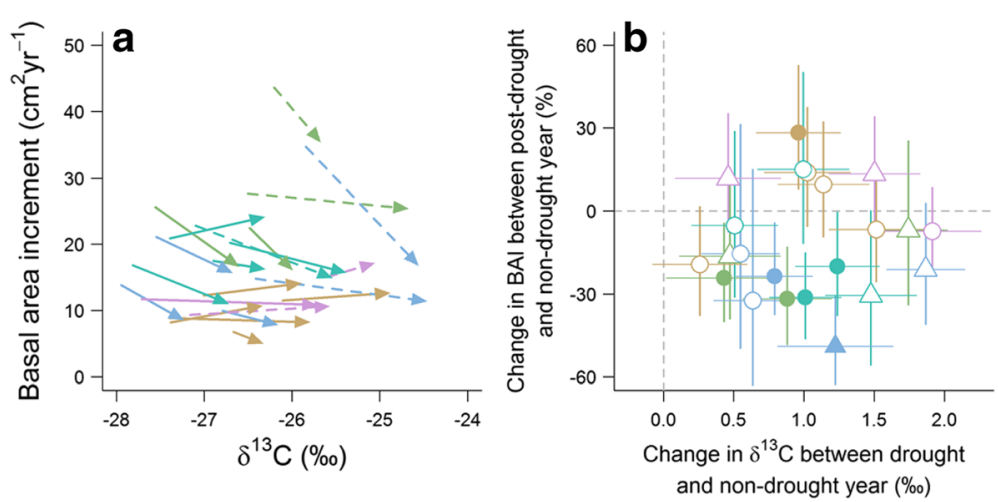

Fig. 4 Relationship between changes in $\delta^{13} \mathrm{C}$ in response to drought and changes in basal area increments (BAl) between drought and one year post-drought years. The interpretation of the figure is analogous to that of Fig. 3. Species from Spain are not shown because for this site the year post-drought coincided with the year that was selected as the non-drought control (see Table 1 for details) 
we be able to develop models that accurately capture the response of forests to extreme events such as severe droughts (Babst et al. 2013; Rammig et al. 2015).

While recent work has shown that stomatal regulation and function can vary considerably among temperate trees (Wolz et al. 2017), carbon isotope changes in response to drought were remarkably consistent across a diverse group of species and a range of environmental conditions (Fig. 2a). For example, even though we found that on average broadleaf species had carbon isotope compositions that were around $1 \%$ lower than those of conifers, the magnitude of the $\delta^{13} \mathrm{C}$ change in response to drought was statistically indistinguishable between the two groups. Similarly, we found no systematic differences in the degree to which $\delta^{13} \mathrm{C}$ increased in response to drought across the six study sites, despite the fact these represent strongly contrasting forest types and environmental conditions. By contrast, growth responses to drought varied considerably among species and study sites (Fig. 2b). Consistently with what has been previously reported in the literature, Norway spruce (Picea abies) emerged as particularly susceptible to drought (e.g., Zang et al. 2014), while species such as Scots pine (Pinus sylvestris) showed greater resistance to drought across a range of provenances. With the exception of trees sampled at the site in Romania and Norway spruce trees from Poland and Germany, the only other species to show significant declines in growth in response to drought was Ostrya carpinifolia. This matches previous reports showing that, relative to other species it typically coexists with, O. carpinifolia can be considered droughtintolerant (Nardini et al. 2016). What is perhaps more interesting is that $O$. carpinifolia was also the only species we sampled to not exhibit a significant increase in $\delta^{13} \mathrm{C}$ following drought. So not only are growth and isotopic responses not coordinated in this species, they are actually contrasting. Further work is needed to shed light on the physiological mechanisms that underpin this result.

Isotopic responses to drought were remarkably conserved even when looking across multiple populations of the same species sampled at different sites along the latitudinal gradient. For instance, Norway spruce trees growing in Germany, Romania and Poland showed almost identical increases in $\delta^{13} \mathrm{C}$ during drought years (matching the strong declines in growth observed at these sites for this species). In Finland, spruce trees did show a less pronounced increase in $\delta^{13} \mathrm{C}$ in response to drought compared to the other three sites. However, this was also associated with a much weaker (and nonsignificant) decline in growth at this site, likely reflecting the lower intensity of the drought event in Finland relative to the other sites (Table 1), as well as the fact that in high-latitude forests photosynthetic activity and growth are primarily limited by temperature rather than by water availability (Babst et al. 2013; Jucker et al. 2016). The same pattern, whereby species sampled at multiple sites exhibited increases in $\delta^{13} \mathrm{C}$ during drought years that were comparable in magnitude, was also found for sycamore (Acer pseudoplatanus), European beech (Fagus sylvatica), sessile oak (Quercus petraea) and Scots pine. The only exception we found to this pattern was birch (Betula pendula), which exhibited a much more pronounced increase in $\delta^{13} \mathrm{C}$ at the site in Finland compared to that in Poland (despite the fact that the drought at the second of these two sites was more intense and lasted longer; Table 1).

In terms of site-specific responses, a clear pattern to emerge from our analysis is that all four species from the site in the Carpathian Mountains of Romania showed very strong declines in growth in response to the drought of 2003 (Fig. 2b). In fact this one site accounted for more than half of the statistically significant growth declines in response to drought we observed across the 26 populations studies here. One possible explanation for this is that while the 2003 drought at the Romanian site reached a lower peak intensity compared to the sites in Italy and Germany (Table 1), drought conditions at the Romanian site began earlier in the year and extended right through to the following growing seasons (see Supporting Information of Grossiord et al. 2014). This would again suggest that critical to understanding the effects of drought on growth is factoring in not just the occurrence, but also the timing, duration and intensity of drought events, as well as the local adaptation or preconditioning of trees to drought. In addition to this, another factor that could have contributed to the strong drought response in Romania is the high basal area of the stands at this site (Table 1), which previous work has shown can modulate the impact of drought on forest growth by exacerbating belowground competition for water (Bottero et al. 2017).

Although we did find some evidence that low soil moisture availability in one year could affect growth trends in the next (Fig. 2c), across our study sites these legacy effects of drought were not as pervasive as reported elsewhere (Anderegg et al. 2015). Instead, legacy effects of drought varied considerably among species, and with few exceptions seemed to reflect slow, progressive recovery from drought rather than a lagged response sensu stricto (which would manifest as little or no change in growth during the drought year, followed by a more pronounced decline in the following year). Overall, this recovery appears to have been faster for conifers than angiosperms, which is consistent with the results of a recent large scale study on forest resilience to drought across the Northern hemisphere (Gazol et al. 2017). Norway spruce for instance showed signs of recovery at three of the four sites where it was sampled. 
By contrast, European beech showed a clear lag phase in its growth response, with both populations studied here exhibiting significantly suppressed growth one year post-drought (Fig. 2c). That being said, accounting for lagged growth responses to drought did not reveal a coordinated response between carbon isotopes ratios and growth under conditions of low soil moisture availability (Fig. 4).

While we attribute the lack of correlation between changes in $\delta^{13} \mathrm{C}$ and ones in BAI to the ability of trees to sustain growth under conditions of low water availability, a number of caveats related to the approach we used to look for associations between $\delta^{13} \mathrm{C}$ and BAI measurements should be kept in mind when interpreting our results. The most important of these is that we were only able to compare a single drought and non-drought year at each site. As mentioned previously, in defining our sampling strategy we chose to maximise the geographic and taxonomic coverage of our dataset in an attempt to provide a first comprehensive test of whether or not carbon isotope ratios and stem growth rates show coordinated responses to drought across Europe's forests. However, this came at the expense of being able to replicate our analysis across multiple drought/non-drought events within each site. In this respect, a fully resolved chronology of both $\delta^{13} \mathrm{C}$ and BAI would have allowed us to more effectively account for legacy effects of climate on growth and isotope ratios. It also would have provided an opportunity to explore how other factors such as vapour pressure deficit, nitrogen availability, insect and pathogen outbreaks, or masting events might affect both $\delta^{13} \mathrm{C}$ and BAI (e.g., Hacket-Pain et al. 2015). Our results clearly suggest that shifts in carbon isotope ratios associated with stomatal regulation during drought do not directly translate into declines in stem growth. Uncovering the physiological processes that underpin these complex patterns is an important next step.

An additional issue with relating $\delta^{13} \mathrm{C}$ and $\mathrm{BAI}$ using our approach which is worth considering is that while BAI integrates growth across the entire year, $\delta^{13} \mathrm{C}$ is calculated exclusively for latewood samples to avoid issues with the remobilization of photosynthates at the beginning of the growing season. As a result, $\delta^{13} \mathrm{C}$ primarily reflects climatic conditions in the later part of the growing season, leading to a potential mismatch with the processes that shape annual trends in BAI. That being said, teasing apart the seasonal dynamics of the drought years we selected suggests this is unlikely to be a major issue in our case. This is because across all study sites we found that the water stress index used to identify drought years had very similar values whether it was calculated across the entire calendar year or whether we restricted it exclusively to the growing season (Table 1). Regardless of this, a more detailed analysis of within-year variation in $\delta^{13} \mathrm{C}$ and BAI that explicitly accounts for carbon remobilization between storage pools would certainly help clarify the physiological mechanisms that underpin both isotopic discrimination and growth (e.g., Helle and Schleser 2004). Lastly, because we had to aggregate samples for isotopic analyses, all of our comparisons between $\delta^{13} \mathrm{C}$ and BAI are made at the population level and potentially ignore important variation among individual trees. In this respect, an advantage of working at the individual tree level would have been the ability to tease apart the effects of tree size on both growth and $\delta^{13} \mathrm{C}$ (e.g., Koch et al. 2004) under varying conditions of soil water availability.

\section{Conclusions}

Across a diverse group of tree species and a range of environmental conditions carbon isotope ratios were strongly influenced by drought, with all but one of the populations sampled in this study exhibiting a significant increase in $\delta^{13} \mathrm{C}$ under drought conditions. However, this strong isotopic signature did not translate into an equally clear growth response to drought, as most tree species were able to maintain growth even under conditions of low soil water availability. As a result, while $\delta^{13} \mathrm{C}$ provides a powerful indicator of past drought occurrence, by themselves carbon isotope ratios tell us little about how carbon sequestration and allocation to wood are affected by conditions of low water availability across Europe's forests.

\section{Abbreviations \\ ${ }^{12} \mathrm{C}$ : Carbon 12 isotope; ${ }^{13} \mathrm{C}$ : Carbon 13 isotope; BAl: Basal area increment (in $\mathrm{cm}^{2}$ ); $\mathrm{BAl}_{\mathrm{dry}+1}$ : BAl one year post-drought (in $\mathrm{cm}^{2}$ ); $\mathrm{BAl} \mathrm{dry}_{\mathrm{dry}}$ : BAl in the drought year (in $\mathrm{cm}^{2}$ ); $\mathrm{BAl}_{\text {wet: }}$ BAl in the wet year (in $\mathrm{cm}^{2}$ ); Cll: Crown illumination index (ordinal, 1 to 5); D: Diameter at breast height (in cm); REW: Relative extractable water in the soil; RuBlsCO: Ribulose-1,5- bisphosphate carboxylase/oxygenase; $\delta^{13} \mathrm{C}$ : Ratio of ${ }^{13} \mathrm{C}$ to ${ }^{12} \mathrm{C}$ (in \%o); $\delta^{13} C_{\text {dry: }} \delta^{13} \mathrm{C}$ in the drought year (in \%); $\delta^{13} C_{\text {wet: }}: \delta^{13} \mathrm{C}$ in the non-drought year (in \%o); $\triangle \mathrm{BAl}$ : Ratio of $\mathrm{BAl}_{\mathrm{dry}}$ to $\mathrm{BAl}_{\text {wet }}$ (in \%); $\triangle \mathrm{BAl}_{\text {lag }}$ : Ratio of $\mathrm{BAl}_{\mathrm{dry}}+1$ to $\mathrm{BAl}_{\text {wet }}$ (in \%); $\Delta \delta^{13} \mathrm{C}$ : Difference between $\delta^{13} \mathrm{C}_{\text {dry }}$ and $\delta^{13} \mathrm{C}_{\text {wet }}$ (in \%o)}

\section{Acknowledgements}

We thank D. Avacaritei, I. Barnoaiea, A. Benneter, I. Dănilă, G. Duduman and L. Nichiforel for assisting with data collection, and FunDivEUROPE site managers for establishing the permanent plots. Comments by three anonymous reviewers helped us improve our paper.

\section{Authors' contributions}

TJ designed the study with input from all co-authors; TJ and CG collected the tree core samples; CG processed the wood samples for isotopic analysis, while TJ reconstructed growth trends for the tree ring data; TJ analysed the data and wrote the first draft of the manuscript, with all authors contributing substantially to revisions.

\section{Funding}

The research leading to these results received funding from the European Union Seventh Framework Programme (FP7/2007-2013) under grant agreement $n^{\circ} 265,171$. 


\section{Competing interests}

The authors declare that they have no competing interests.

\section{Author details}

${ }^{1}$ Ecosystem Change Ecology team, CSIRO Land and Water, 147 Underwood Avenue, Floreat, WA 6014, Australia. ${ }^{2}$ Forest Ecology and Conservation group, Department of Plant Sciences, University of Cambridge, Cambridge, UK. ${ }^{3}$ Earth and Environmental Sciences Division, Los Alamos National Laboratory, Los Alamos, NM 87545, USA. ${ }^{4}$ INRA, Université de Lorraine, UMR EEF, Allée de l'Arboretum, 54280 Champenoux, France. ${ }^{5}$ Stefan cel Mare University, Strada Universității 13, 720229 Suceava, Romania. ${ }^{6}$ Swiss Federal Institute for Forest, Snow and Landscape Research WSL, Forest Dynamics, 8903 Birmensdorf, Switzerland.

\section{Received: 28 July 2017 Accepted: 9 October 2017}

Published online: 05 December 2017

\section{References}

Allen CD, Breshears DD, McDowell NG (2015) On underestimation of global vulnerability to tree mortality and forest die-off from hotter drought in the Anthropocene. Ecosphere 6:129. https://doi.org/10.1890/ES15-00203.1

Anderegg WRL, Schwalm C, Biondi F, Camarero JJ, Koch G, Litvak M, Ogle K, Shaw JD, Shevliakova E, Williams AP, Wolf A, Ziaco E, Pacala S (2015) Pervasive drought legacies in forest ecosystems and their implications for carbon cycle models. Science 349:528-532. DOI: 10.1126/science.aab1833

Babst F, Poulter B, Trouet V, Tan K, Neuwirth B, Wilson R, Carrer M, Grabner M, Tegel W, Levanic T, Panayotov M, Urbinati C, Bouriaud O, Ciais P, Frank D (2013) Site- and species-specific responses of forest growth to climate across the European continent. Glob Ecol Biogeogr 22:706-717. https://doi.org/10. 1111 /geb.12023

Baeten L, Verheyen K, Wirth C, Bruelheide H, Bussotti F, Finér L, Jaroszewicz B, Selvi $F$, Valladares F, Allan E, Ampoorter $E$, Auge $H$, Avăcăriei $D$, Barbaro $L$, Bărnoaiea I, Bastias CC, Bauhus J, Beinhoff C, Benavides R, Benneter A, Berger S, Berthold F, Boberg J, Bonal D, Brüggemann W, Carnol M, Castagneyrol B, Charbonnier Y, Chećko E, Coomes DA, Coppi A, Dalmaris E, Dănilă G, Dawud SM, de Vries W, De Wandeler H, Deconchat M, Domisch T, Duduman G, Fischer M, Fotelli M, Gessler A, Gimeno TE, Granier A, Grossiord C, Guyot V, Hantsch L, Hättenschwiler S, Hector A, Hermy M, Holland V, Jactel H, Joly F-X, Jucker T, Kolb S, Koricheva J, Lexer MJ, Liebergesell M, Milligan H, Müller S, Muys B, Nguyen D, Nichiforel L, Pollastrini M, Proulx R, Rabasa S, Radoglou K, Ratcliffe S, Raulund-Rasmussen K, Seiferling I, Stenlid J, Vesterdal L, von Wilpert K, Zavala MA, Zielinski D, Scherer-Lorenzen M (2013) A novel comparative research platform designed to determine the functional significance of tree species diversity in European forests. Perspect Plant Ecol Evol Syst 15:281-291. https://doi.org/10.1016/j.ppees.2013.07.002

Beer C, Reichstein M, Tomelleri E, Ciais P, Jung M, Carvalhais N, Rodenbeck C, Arain MA, Baldocchi D, Bonan GB, Bondeau A, Cescatti A, Lasslop G, Lindroth A, Lomas MR, Luyssaert S, Margolis H, Oleson KW, Roupsard O, Veenendaal E, Viovy N, Williams C, Woodward IF, Papale D (2010) Terrestrial gross carbon dioxide uptake: global distribution and covariation with climate. Science 329: 834-838. doi:10.1126/science.1184984

Belmecheri S, Maxwell RS, Taylor AH, Davis KJ, Freeman KH, Munger WJ (2014) Treering $813 \mathrm{C}$ tracks flux tower ecosystem productivity estimates in a NE temperate forest. Environ Res Lett 9:74011. https://doi.org/10.1088/1748-9326/9/7/074011

Bennett AC, McDowell NG, Allen CD, Anderson-Teixeira KJ, Trenberth KE, Nepstad DC, Tohver IM, Ray D, Moutinho P, Cardinot G, Phillips OL, Lindenmayer DB, Laurance WF, Franklin JF, Lutz JA, Larson AJ, Swanson ME, Freund JA, Wullschleger SD, Hanson P, Todd D, Meinzer FC, Stahl C, Ryan MG, Phillips N, Bond BJ, Zhang Y-J, MCDowell NG, Allen CD, Roberts J, Cabral OMR, Aguiar LF, Pfeifer EM, Hicke JA, Meddens AJH, Chapin FS, Randerson JT, McGuire AD, Foley JA, Field CB, Jiang X, Allen CD, Breshears DD, Van NMGL, Sheil D, Condit R, Hubbell SP, Foster RB, Mueller RC, Anderson-Teixeira KJ, Poorter H, Condit R, Laurance WF, Williamson GB, Doughty CE, da CACL, Mattson WJ, Haack RA (2015) Larger trees suffer most during drought in forests worldwide. Nat Plants 1:15139. https://doi.org/10.1038/nplants.2015.139

Boisvenue C, Running SW (2006) Impacts of climate change on natural forest productivity - evidence since the middle of the 20th century. Glob Chang Biol 12:862-882. https://doi.org/10.1111/j.1365-2486.2006.01134.x

Bottero A, D'Amato AW, Palik BJ, Bradford JB, Fraver S, Battaglia MA, Asherin LA (2017) Density-dependent vulnerability of forest ecosystems to drought. J Appl Ecol. https://doi.org/10.1111/1365-2664.12847
Bréda N, Huc R, Granier A, Dreyer E (2006) Temperate forest trees and stands under severe drought: a review of ecophysiological responses, adaptation processes and long-term consequences. Ann For Sci 63:625-644. https://doi. org/10.1051/forest:2006042

Caspersen JP, Vanderwel MC, Cole WG, Purves DW (2011) How stand productivity results from size- and competition-dependent growth and mortality. PLoS One 6:e28660. https://doi.org/10.1371/journal.pone.0028660

Clark DA, Clark DB (1992) Life history diversity of canopy and emergent trees in a neotropical rain forest. Ecol Monogr 62:315-344. doi:10.2307/2937114

Clark JS, Iverson L, Woodall CW, Allen CD, Bell DM, Bragg DC, D'Amato AW, Davis FW, Hersh MH, Ibanez I, Jackson ST, Matthews S, Pederson N, Peters M, Schwartz MW, Waring KM, Zimmermann NE (2016) The impacts of increasing drought on forest dynamics, structure, and biodiversity in the United States. Glob Chang Biol 22:2329-2352. https://doi.org/10.1111/gcb.13160

Core Development Team R (2016) R: a language and environment for statistical computing. R Foundation for Statistical Computing, Vienna, Austria

Dietze MC, Sala A, Carbone MS, Czimczik Cl, Mantooth JA, Richardson AD, Vargas $R$ (2014) Nonstructural carbon in woody plants. Annu Rev Plant Biol 65:667687. https://doi.org/10.1146/annurev-arplant-050213-040054

EEA (2007) European Forest types. Categories and types for sustainable forest management reporting and policy, 2nd edn. European Environment Agency, Copenhagen EEA technical report 09/2006

Farquhar G, O'Leary M, Berry J (1982) On the relationship between carbon isotope discrimination and the intercellular carbon dioxide concentration in leaves. Aust J Plant Physiol 9:121-137. https://doi.org/10.1071/PP9820121

Farquhar GD, Ehleringer JR, Hubick KT (1989) Carbon isotope discrimination and photosynthesis. Annu Rev Plant Physiol Plant Mol Biol 40:503-537. https:// doi.org/10.1146/annurev.pp.40.060189.002443

Ferrio AJP, Florit A, Vega A, Serrano L, Voltas J, Ferrio JP, Florit A, Vega A, Serrano L, Voltas J (2003) $\Delta 13 C$ and tree-ring width reflect different drought responses in Quercus Ilex and Pinus Halepensis. Ecophysiology 442:512-518. https://doi.org/10.1007/s00442-003-1372-7

Ferrio JP, Voltas J, Araus JL (2003) Use of carbon isotope composition in monitoring environmental changes. Manag Environ Qual An Int J 14:82-98. https://doi.org/10.1108/14777830310460405

Frank D, Reichstein M, Bahn M, Thonicke K, Frank D, Mahecha MD, Smith P, van der Velde M, Vicca S, Babst F, Beer C, Buchmann N, Canadell JG, Ciais P, Cramer W, Ibrom A, Miglietta F, Poulter B, Rammig A, Seneviratne SI, Walz A, Wattenbach M, Zavala MA, Zscheischler J (2015) Effects of climate extremes on the terrestrial carbon cycle: concepts, processes and potential future impacts. Glob Chang Biol 21:2861-2880. https://doi.org/10.1111/gcb.12916

Friend AD, Lucht W, Rademacher TT, Keribin R, Betts R, Cadule P, Ciais P, Clark DB, Dankers R, Falloon PD, Ito A, Kahana R, Kleidon A, Lomas MR, Nishina K, Ostberg S, Pavlick R, Peylin P, Schaphoff S, Vuichard N, Warszawski L, Wiltshire A, Woodward FI (2014) Carbon residence time dominates uncertainty in terrestrial vegetation responses to future climate and atmospheric CO2. Proc Natl Acad Sci 111:3280-3285. https://doi.org/10.1073/ pnas. 1222477110

Gazol A, Camarero JJ, Anderegg WRL, Vicente-Serrano SM (2017) Impacts of droughts on the growth resilience of northern hemisphere forests. Glob Ecol Biogeogr 26:166-176. https://doi.org/10.1111/geb.12526

Gessler A, Ferrio JP, Hommel R, Treydte K, Werner RA, Monson RK (2014) Stable isotopes in tree rings: towards a mechanistic understanding of isotope fractionation and mixing processes from the leaves to the wood. Tree Physiol 34:796-818. https://doi.org/10.1093/treephys/tpu040

Granier A, Bréda N, Biron P, Villette S (1999) A lumped water balance model to evaluate duration and intensity of drought constraints in forest stands. Ecol Model 116:269-283. https://doi.org/10.1016/S0304-3800(98)00205-1

Grossiord C, Granier A, Gessler A, Jucker T, Bonal D (2014) Does drought influence the relationship between biodiversity and ecosystem functioning in boreal forests? Ecosystems 17:394-404. https://doi.org/10. 1007/s10021-013-9729-1

Grossiord C, Granier A, Ratcliffe S, Bouriaud O, Bruelheide H, Chećko E, Forrester DI, Dawud SM, Finér L, Pollastrini M, Scherer-Lorenzen M, Valladares F, Bonal D, Gessler A (2014) Tree diversity does not always improve resistance of forest ecosystems to drought. Proc Natl Acad Sci 111:14812-14815. https:// doi.org/10.1073/pnas.1411970111

Grossiord C, Sevanto S, Borrego I, Chan AM, Collins AD, Dickman LT, Hudson PJ, McBranch N, Michaletz ST, Pockman WT, Ryan M, Vilagrosa A, McDowell NG (2017) Tree water dynamics in a drying and warming world. Plant Cell Environ:1-13. https://doi.org/10.1111/pce.12991 
Grote R, Gessler A, Hommel R, Poschenrieder W, Priesack E (2016) Importance of tree height and social position for drought-related stress on tree growth and mortality. Trees - Struct Funct 30:1467-1482. https:// doi.org/10.1007/s00468-016-1446-x

Hacket-Pain AJ, Friend AD, Lageard JGA, Thomas PA (2015) The influence of masting phenomenon on growth-climate relationships in trees: explaining the influence of previous summers' climate on ring width. Tree Physiol 35: 319-330. https://doi.org/10.1093/treephys/tpv007

Helle G, Schleser GH (2004) Beyond CO2-fixation by Rubisco - an interpretation of $13 \mathrm{C} / 12 \mathrm{C}$ variations in tree rings from novel intra-seasonal studies on broad-leaf trees. Plant Cell Environ 27:367-380. https://doi.org/10.1111/j.00168025.2003.01159.x

Hentschel R, Hommel R, Poschenrieder W, Grote R, Holst J, Biernath C, Gessler A, Priesack E (2016) Stomatal conductance and intrinsic water use efficiency in the drought year 2003: a case study of a well-established forest stand of European beech. Trees 30:153-174. https:/doi.org/10.1007/s00468-015-1284-2

Jansen K, Sohrt J, Kohnle U, Ensminger I, Gessler A (2013) Tree ring isotopic composition, radial increment and height growth reveal provenance-specific reactions of Douglas-fir towards environmental parameters. Trees - Struct Funct 27:37-52. https://doi.org/10.1007/s00468-012-0765-9

Jennings SB, Brown ND, Sheil D (1999) Assessing forest canopies and understorey illumination: canopy closure, canopy cover and other measures. Forestry 72:59-73

Jucker T, Avăcăriței D, Bărnoaiea I, Duduman G, Bouriaud O, Coomes DA (2016) Climate modulates the effects of tree diversity on forest productivity. J Ecol 104:388-398. https://doi.org/10.1111/1365-2745.12522

Jucker T, Bouriaud O, Avăcăriei D, Coomes DA (2014) Stabilizing effects of diversity on aboveground wood production in forest ecosystems: linking patterns and processes. Ecol Lett 17:1560-1569. https://doi.org/10.1111/ ele.12382

Jucker T, Bouriaud O, Avăcăriei D, Dănilă I, Duduman G, Valladares F, Coomes DA (2014) Competition for light and water play contrasting roles in driving diversity-productivity relationships in Iberian forests. J Ecol 102:1202-1213. https://doi.org/10.1111/1365-2745.12276

Koch GW, Sillett SC, Jennings GM, Davis SD (2004) The limits to tree height. Nature 428:851-854. https://doi.org/10.1038/nature02417

Leary MH (1988) Carbon isotopes in photosynthesis. Bioscience 38:328-336

Leavitt SW (1993) Environmental information from 13C/12C ratios of wood. In: Swart PK, Lohmann KC, Mckenzie J, Savin S (eds) Climate change in continental isotopic records. American Geophysical Union, Geophysical eMonograph Series, vol 78, pp 325-331

Luyssaert S, Schulze E-DE-D, Börner A, Knohl A, Hessenmöller D, Law BE, Ciais P, Grace J (2008) Old-growth forests as global carbon sinks. Nature 455:213215. https://doi.org/10.1038/nature07276

Nardini A, Casolo V, Dal Borgo A, Savi T, Stenni B, Bertoncin P, Zini L, Mcdowell NG (2016) Rooting depth, water relations and non-structural carbohydrate dynamics in three woody angiosperms differentially affected by an extreme summer drought. Plant Cell Environ 39:618-627. https://doi.org/10.1111/pce.12646

Offermann C, Ferrio JP, Holst J, Grote R, Siegwolf R, Kayler Z, Gessler A (2011) The long way down - are carbon and oxygen isotope signals in the tree ring uncoupled from canopy physiological processes? Tree Physiol 31:1088-1102. https://doi.org/10.1093/treephys/tpr093

Pan Y, Birdsey RA, Fang J, Houghton RA, Kauppi PE, Kurz WA, Phillips OL, Shvidenko A, Lewis SL, Canadell JG, Ciais P, Jackson RB, Pacala SW, McGuire AD, Piao S, Rautiainen A, Sitch S, Hayes D, Canadell JG, Khatiwala S, Primeau F, Hall T, Le QC, Dixon RK, Kauppi PE, Kurz WA, Stinson G, Rampley GJ, Dymond CC, Neilson ET, Stinson G, Birdsey RA, Pregitzer K, Lucier A, Kauppi PE, Pan Y, Pan Y, Birdsey RA, Hom J, McCullough K, van MPJ, Breshears DD, Ciais P, Fang J, Chen A, Peng C, Zhao S, Ci L, Lewis SL, Phillips OL, Gloor M, Lewis SL, Lloyd J, Sitch S, Mitchard ETA, Laurance WF, Houghton RA, Friedlingstein P, Tarnocai C, Hooijer A, Page SE, Rieley JO, Banks CJ, McGuire AD, Goodale CL, Sarmiento JL, Schulze ED, Pacala SW, Phillips OL, Metsaranta JM, Kurz WA, Neilson ET, Stinson G, Zhao M, Running SW, Houghton RA (2011) A large and persistent carbon sink in the world's forests. Science 333: 988-993. https://doi.org/10.1126/science.1201609

Peñuelas J, Hunt JM, Ogaya R, Jump AS (2008) Twentieth century changes of tree-ring $813 \mathrm{C}$ at the southern range-edge of Fagus Sylvatica: increasing water-use efficiency does not avoid the growth decline induced by warming at low altitudes. Glob Chang Biol 14:1076-1088. https://doi.org/10.1111/j. 1365-2486.2008.01563.x
Rammig A, Wiedermann M, Donges JF, Babst F, Von Bloh W, Frank D, Thonicke K, Mahecha MD (2015) Coincidences of climate extremes and anomalous vegetation responses: comparing tree ring patterns to simulated productivity. Biogeosciences 12:373-385. https://doi.org/10.5194/bg-12-373-2015

Rüger N, Wirth C, Wright SJ, Condit R (2012) Functional traits explain light and size response of growth rates in tropical tree species. Ecology 93:2626-2636

Shestakova TA, Camarero JJ, Ferrio JP, Knorre AA, Gutierrez E, Voltas J (2017) Increasing drought effects on five European pines modulate $813 \mathrm{C}$-growth coupling along a Mediterranean altitudinal gradient. Funct Ecol:1359-1370. https://doi.org/10.1111/1365-2435.12857

Warren CR, McGrath JF, Adams MA (2001) Water availability and carbon isotope discrimination in conifers. Oecologia 127:476-486. https://doi.org/10.1007/ s004420000609

Wolz KJ, Wertin TM, Abordo M, Wang D, Leakey ADB (2017) Diversity in stomatal function is integral to modelling plant carbon and water fluxes. Nat Ecol Evol. https://doi.org/10.1038/s41559-017-0238-z

Zang C, Hartl-Meier C, Dittmar C, Rothe A, Menzel A (2014) Patterns of drought tolerance in major European temperate forest trees: climatic drivers and levels of variability. Glob Chang Biol 20:3767-3779. https:// doi.org/10.1111/gcb.12637

Zang C, Pretzsch H, Rothe A (2012) Size-dependent responses to summer drought in scots pine, Norway spruce and common oak. Trees - Struct Funct 26:557-569. https://doi.org/10.1007/s00468-011-0617-z

\section{Submit your manuscript to a SpringerOpen ${ }^{\circ}$ journal and benefit from:}

- Convenient online submission

- Rigorous peer review

- Open access: articles freely available online

- High visibility within the field

- Retaining the copyright to your article

Submit your next manuscript at springeropen.com 